\title{
Pernicious anaemia and mucosal endocrine cell proliferation of the non-antral stomach
}

\author{
J RODE, A P DHILLON, LUCIENNE PAPADAKI, R STOCKBRÜGGER, \\ R J THOMPSON, E MOSS, AND P B COTTON \\ From the Bland-Sutton Institute of Pathology, The Middlesex Hospital Medical School, London, Department \\ of Medicine II, Sahlgren's Hospital, Gothenburg, Sweden, Department of Clinical Biochemistry, School of \\ Clinical Medicine, Addenbrooke's Hospital, Cambridge, and the Department of Gastroenterology, The \\ Middlesex Hospital, London
}

SUMMARY There is a recognised association between pernicious anaemia and the development of gastric carcinoma, endocrine cell hyperplasia, and carcinoid tumour. Multiple endoscopic biopsies from the body mucosa of seven patients with pernicious anaemia showed small intestinal metaplasia with varying degrees of inflammation, fibrosis, and expansion of the lamina propria. Using conventional silver and lead stains, endocrine cells were inconspicuous. Staining for the general neural and neuroendocrine markers NSE and PGP 9.5 revealed a proliferation of endocrine cells in the epithelium and isolated clumps of endocrine cells in the lamina propria. The clumps were composed of two cell types, either small or large. Some of these endocrine cells showed gastrin, 5HT, VIP and substance $\mathrm{P}$ immunoreactivity of varying intensity. Ultrastructurally nine morphologically distinct types of granules were found some of which correlated with the immunohistochemistry. Some separate islands were composed solely of endocrine cells while others had a definite neural component, suggesting that the former arise from 'budding off' of enteroendocrine cells and the latter originate from the neuroendocrine cells of the lamina propria plexus. Thus there may be a dual origin of carcinoid tumours. Carcinoid tumours associated with pernicious anaemia tend to be multifocal and are infrequent. Less than 50 such cases have hitherto been reported. Our findings of endocrine cells proliferations in seven cases of pernicious anaemia indicate that this may be an adaptive change that occurs frequently and provides the basis on which carcinoids, less frequently, develop.

The term 'carcinoid' encompasses morphologically similar but functionally heterogeneous neoplasms which are most frequently found in organs derived from the primitive gut but can occur in almost any extra-intestinal site. ${ }^{1}$ The histogenesis, pathogenesis, and biological behaviour of these tumours are subjects of continual debate. ${ }^{12}$ Clearly, new approaches to diagnosis and classifications are needed in order to provide data not only on the evolution of these tumours but also to predict the likelihood of metastasis.

Classically, carcinoid tumours of the gastrointestinal tract are thought to arise from enteroendocrine cells within crypt or glandular epithelium. Recently, however, it has been suggested that such neoplasms

Address for correspondence: Dr J Rode. The Bland-Sutton Institute of Pathology, The Middlesex Hospital Medical School, London W1P 7PN. Received for publication 3 October 1985 may originate from neuroendocrine cells within a neural plexus in the lamina propria. ${ }^{34}$ Although gastric carcinoids are uncommon, an association of pernicious anaemia with gastric endocrine celi hyperplasia was found by Rubin in $1969^{5}$ and later extended to include carcinoid tumours. ${ }^{6}$ The mechanism of this association stems from an atrophic gastritis which leads to an endocrine cell hyperplasia. This latter is probably caused by the lack of feedback inhibition on endocrine cell proliferation caused by a decreased gastric acid production. ${ }^{78}$ In addition, the raised gastrin concentrations may stimulate proliferation of the gastric enterochromaffin-like cells. ${ }^{9}$ The resulting endocrine lesions appear to contain both argentaffin and argyrophilic cells, of which several morphological cell types have been described 571011 and some shown, immunohistochemically, to be gastrin 
containing. ${ }^{12}{ }^{13}$ In order to further characterise the types of endocrine cells present and to elucidate the histogenesis of carcinoids of the non-antral stomach both immunohistochemical and fine structural studies were carried out on portions of gastroscopic biopsies from seven patients with pernicious anaemia.

\section{Methods}

PATIENTS

Seven patients with pernicious anaemia from a larger series of 80 underwent an upper gastrointestinal endoscopy four years after an initial examination. ${ }^{14}$ The patients' age, sex, and duration of pernicious anaemia are given in Table 1. Most of the patients were controlled because of various degrees of dysplasia of the gastric antral or body mucosa at the first examination but two patients (nos 4 and 5) had known endocrine cell proliferations in the lamina propria of the stomach body.

\section{TISSUES}

Six biopsies from each patient were obtained during fibreoptic endoscopy from the body of the stomach and immediately fixed in phosphate buffered formalin ( $\mathrm{pH} \mathrm{7.4).} \mathrm{After} \mathrm{fixation} \mathrm{the} \mathrm{specimens} \mathrm{of} \mathrm{each}$ case were divided into equal numbers for separate processing for light and electron microscopy.

For conventional light and immunohistochemistry the specimens were routinely paraffin embedded and serially sectioned at $5 \mu \mathrm{m}$. Consecutive sections were then stained with haematoxylin and eosin (H \& E), an alcian blue/periodic acid - Schiff diastase/lead haematoxylin sequence (AB-PASD$\mathrm{PbH})$ to identify differentially intra- and extraepithelial neuroendocrine cells, ${ }^{3}$ and immunohistochemically for the general neural and neuroendocrine markers neurone specific enolase (NSE) ${ }^{3}$ and protein gene product $9 \cdot 5$ (PGP $9 \cdot 5),{ }^{15} \mathrm{~S} 100$ protein, gastrin, 5HT, somatostatin (S), substance $\mathrm{P}(\mathrm{SP})$, vasoactive intestinal polypeptide (VIP), calcitonin, ACTH, insulin and glucagon. Identically fixed and processed material obtained from the gastric body of four cases with normal histology were included in the series as controls.

For electron microscopy the tissue samples were postfixed in phosphate buffered $1 \%$ osmium tetroxide, dehydrated and embedded in araldite. Semithin sections were stained with toluidine blue and used for light microscopical orientation. Thin sections were stained with uranyl acetate and lead citrate and examined in a Joel $100 \mathrm{~S}$ electron microscope.

\section{Results}

ENDOSCOPICAL FINDINGS

In the two patients with known endocrine cell proliferations multiple polypoid lesions ranging from 1-8 $\mathrm{mm}$ were found in the gastric body mucosa. In patient no 4 more than 50 such lesions were seen, some of them eroded at the surface. In patient no 5 only 11 polyps were counted. These were smaller than in patient no 4 and showed signs of increased vascularisation. Endoscopic findings in the remaining five patients were inconspicuous except for varying degrees of mucosal atrophy in the body and one small polyp in patient no 7 (Table 1).

\section{CONVENTIONAL LIGHT MICROSCOPY}

The findings by conventional light microscopy and immunohistochemistry are summarised in Table 2.

$\mathrm{H}$ \& $\mathrm{E}$ stained sections of the gastric body biopsies of all seven patients showed moderate to marked loss of specialised glands with small intestinal and pseudopyloric metaplasia of varying severity. The gastric glands between the superficial foveolar region and the pyloric type glands were

Table 1

\begin{tabular}{|c|c|c|c|c|c|c|c|}
\hline \multirow[b]{2}{*}{ Patient no } & \multirow[b]{2}{*}{ Initials } & \multirow[b]{2}{*}{$\operatorname{Sex}$} & \multirow{2}{*}{$\begin{array}{l}\text { Age at } \\
\text { examination }\end{array}$} & \multirow{2}{*}{$\begin{array}{l}\text { Age at } \\
\text { pernicious } \\
\text { diagnosis }\end{array}$} & \multirow{2}{*}{$\begin{array}{l}\text { Reason for } \\
\text { follow up }\end{array}$} & \multicolumn{2}{|c|}{ Endoscopic findings } \\
\hline & & & & & & Antrum & Body \\
\hline 1 & SB & $\mathbf{F}$ & 26 & 19 & D1 (A) & Inflammation & Atrophy \\
\hline 2 & NC & $\mathbf{F}$ & 44 & 25 & D2 (B) & Inflammation & Atrophy \\
\hline 3 & $\mathrm{JB}$ & $\mathbf{F}$ & 47 & 38 & D1 (A) & Normal & Atrophy \\
\hline 4 & LC & $\mathbf{F}$ & 50 & 43 & $\mathrm{ECH}(\mathrm{B})$ & Normal & $\begin{array}{l}\text { Multiple polyps } \\
1-8 \mathrm{~mm}\end{array}$ \\
\hline 5 & SS & $\mathbf{M}$ & 54 & 41 & $\mathrm{ECH} \mathrm{(B)}$ & Normal & $\begin{array}{l}\text { Multiple polyps } \\
<3 \mathrm{~mm}\end{array}$ \\
\hline 6 & DF & $\mathbf{M}$ & 70 & 56 & D0 & Normal & Atrophy \\
\hline 7 & $\mathbf{K M}$ & $\mathbf{F}$ & 80 & 73 & $\begin{array}{l}\text { D3 in } \\
\text { polyp (B) }\end{array}$ & Normal & $\begin{array}{l}\text { Atrophy } \\
1 \text { polyp }\end{array}$ \\
\hline
\end{tabular}

$\mathrm{D}=$ Dysplasia $; 0=$ none, $1=$ mild $; 2=$ moderate; $3=$ severe $(\mathrm{A})=$ antrum $;(\mathrm{B})=$ body $; \mathrm{ECH}=$ endocrine cell hyperplasia. 


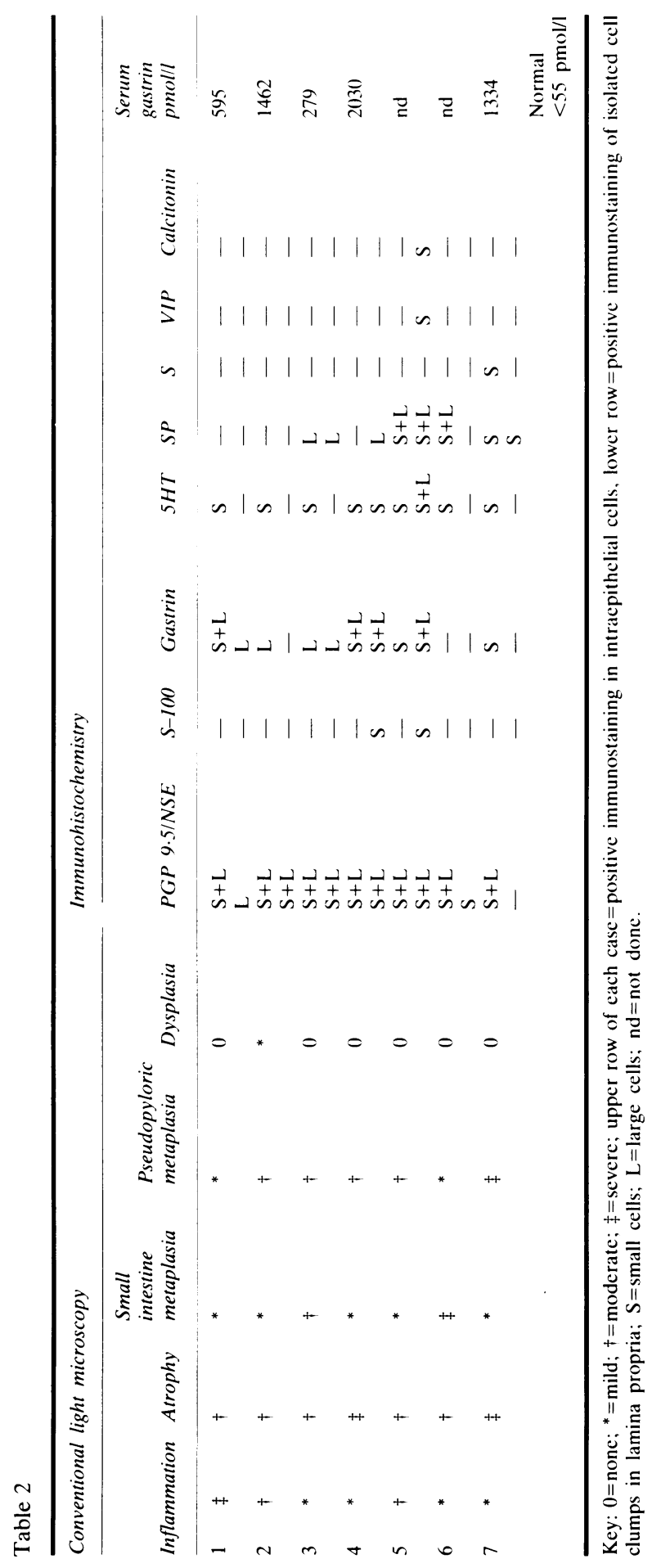


either completely or to a great extent replaced by apparently proliferating non-specialised cells of varying size, hence termed 'the proliferative compartment' (Fig. 1). Active inflammation varied from mild to severe. The connective tissue of the lamina propria was increased in all cases. After staining with the AB-PAS-D-PbH sequence, neurosecretory granules were noted within small cells of the proliferative compartment and Kultschitzky type cells in areas of small intestinal metaplasia.

\section{IMMUNOHISTOCHEMISTRY}

NSE and PGP 9.5

Immunohistochemical staining with the general neural and neuroendocrine markers NSE and PGP 9.5 revealed an increase of nerve fibres within the increased connective tissue of the lamina propria and a remarkable increase of neuroendocrine cells within the proliferative glandular compartment.

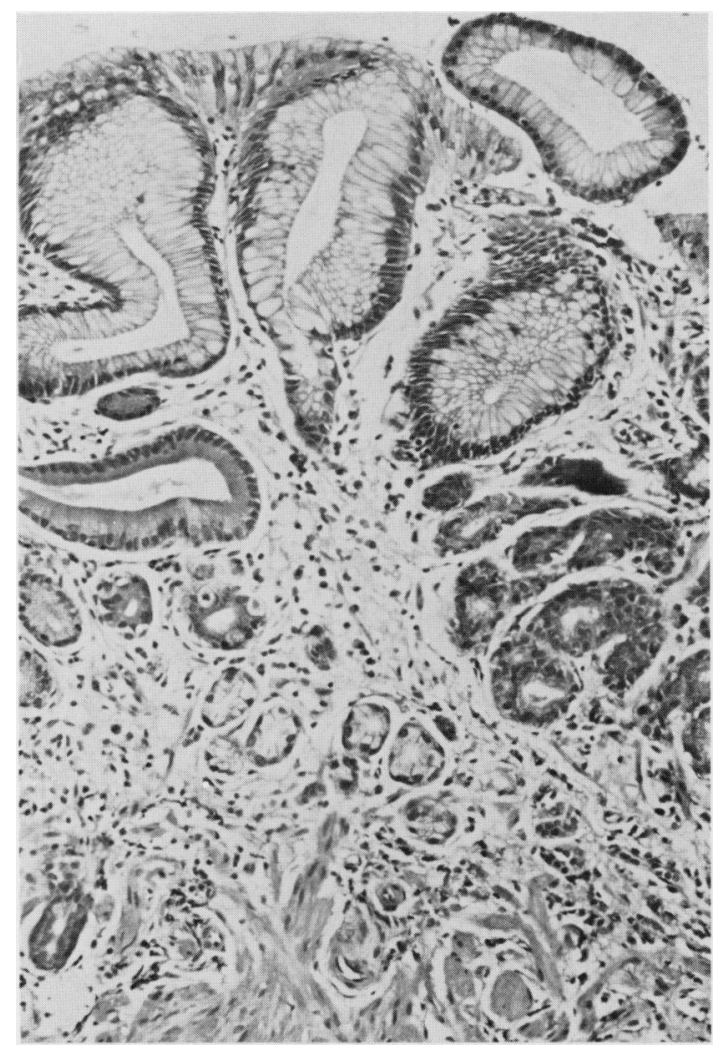

Fig. 1 Gastric body mucosa showing moderate atrophy, mild chronic inflammation, focal small intestinal metaplasia and pseudopyloric metaplasia. Between the superficial foveolae and deep pyloric type glands there is partial replacement of specialised glands by proliferating nonspecialised epithelium. $H \&$ E stain.
Staining for S100 protein in order to demonstrate concomitant Schwann cell proliferation was unhelpful. The positive NSE and PGP 9.5 cells varied in appearance from small basally located cells to larger cells which, in $\mathrm{H} \& \mathrm{E}$ stained sections, had pale or clear cytoplasm and round to ovoid nuclei with a delicate chromatin pattern. In most instances these larger cells had only shown equivocal fine granular staining within their cytoplasm after staining with AB-PASD-PbH but they also had displayed faint PAS-D positivity suggesting neutral mucin production. Often these larger cells were seen enveloping the proliferative compartment in a sleeve-like manner (Fig. 2) or to form small aggregates attached to the glands in a bud-like fashion. Rare endocrine type cells were located within the pyloric type glands.

The most impressive pathological finding after staining for NSE and PGP 9.5 were isolated extraepithelial cell clumps (Fig. 3a and b), islands or larger cohesive sheets composed solely of neuroendocrine cells. These occurred in all cases but one, the oldest patient of the series. The smaller aggre-

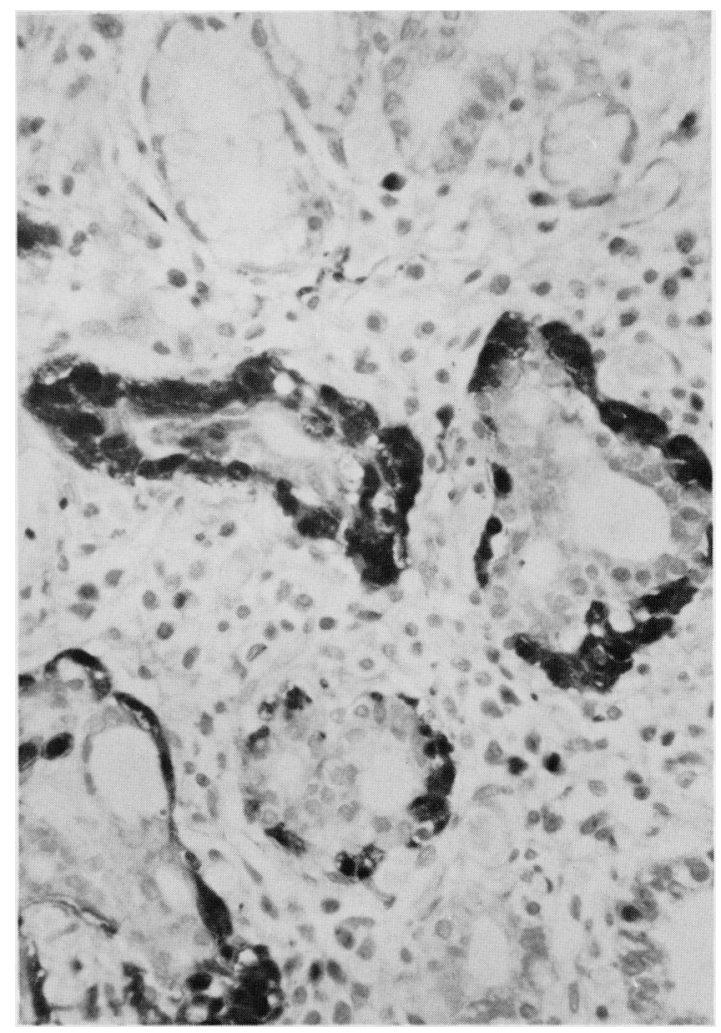

Fig. 2 Sleevelike periglandular proliferations of endocrine cells in the proliferative compartment staining for PGP 9.5. 
gates appeared to be of two types: either composed of large cells similar to the pale cells in the proliferative compartment and measuring up to $20 \mu \mathrm{m}$ in diameter or of smaller cells with regular, more ovoid and compact nuclei and measuring up to $15 \mu \mathrm{m}$ in diameter. The sheet like cell proliferations were entirely made up of larger clear cells. Mitoses were not encountered among either of these cell types. The number of immunoreactive extraepithelial cell aggregates varied from rare to numerous. One case showed only clumps composed of small cells and in another only large cell aggregates were seen. In four cases clumps of both types were present and in one case (case no 4 ) penetration of the muscularis mucosae by large cells was present. The relationship of the extraepithelial neuroendocrine cell aggregates with nerve fibres was difficult to assess at the light microscopic level. Nevertheless, in one case definite close association of small cell clumps with nerve fibres could be recognised (Fig. $3 b)$ and two others contained small cell clumps immunoreactive for $\mathrm{S} 100$ protein. Demonstration of lead haematoxylin positive cytoplasmic granules in these extraepithelial neuroendocrine cells was inconsistent. In the large cells faint granulation could rarely be detected with confidence but occasional small cell clumps showed definite lead haematoxylin

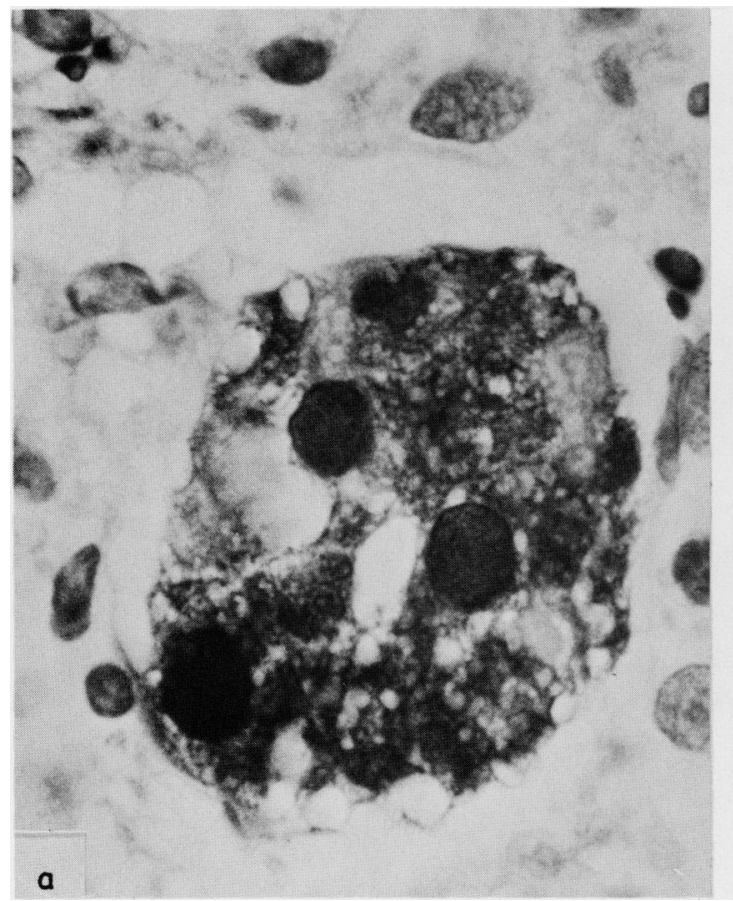

positivity. Both cell types, though, contained fine PAS-D positive droplets.

\section{Gastrin}

Upon staining for gastrin, small basally located, moderately to intensely positive cells were found within the proliferative compartment and occasionally within the pyloric type glands. Most of the intraepithelial large cell proliferations expressed gastrin immunoreactivity. The extraepithelial small and large cell clumps generally showed some cells with gastrin immunoreactivity of moderate intensity (Fig. 4a) but occasional clumps were negative.

\section{5-hydroxytryptamine $(5 H T)$}

As expected, 5HT was expressed consistently in the Kultschitsky type cells in areas of small intestinal metaplasia. In addition, there were varying numbers of small basally located 5HT-positive cells within the proliferative compartment. Occasionally similar cells in the pyloric type glands displayed 5HT immunoreactivity. Only in one case did small and large cell clumps show moderate and marked staining respectively for $5 \mathrm{HT}$ (Fig. 4b) and a further case had a small cell clump with several peripheral moderately staining cells.

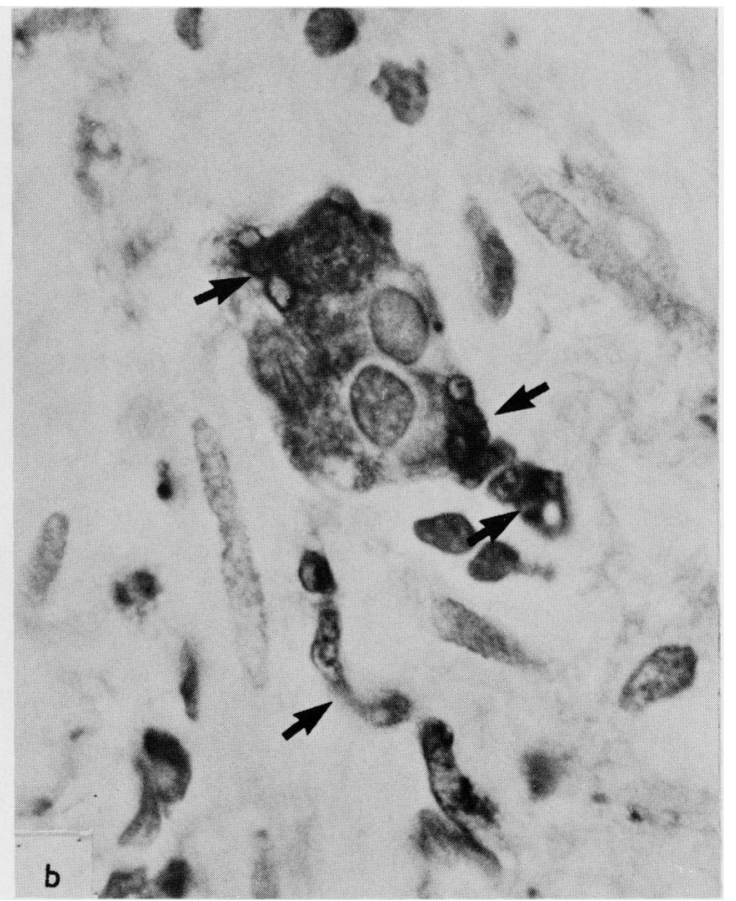

Fig. 3 (a) Isolated clump of large cell type endocrine cells in the lamina propria, (b) clump of apparently innervated (arrows) small type endocrine cells staining for PGP 9.5. 

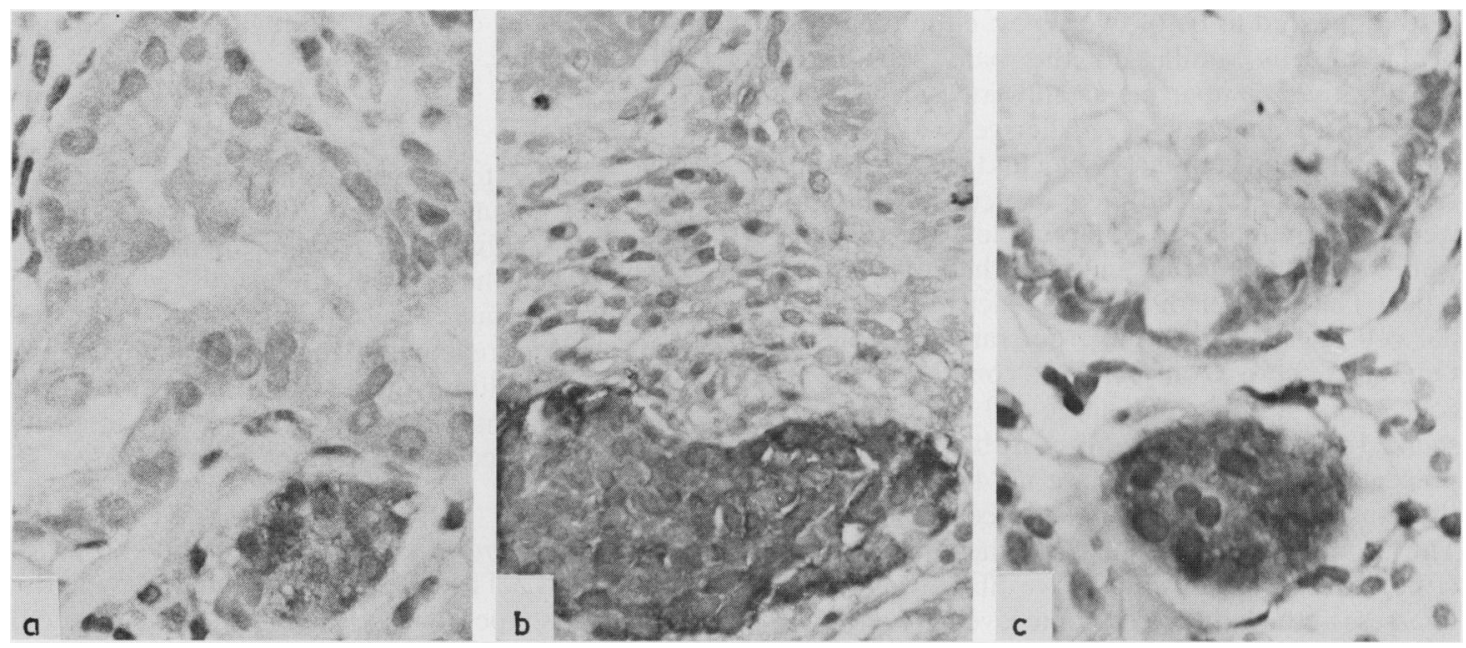

Fig. 4 (a) Clump of large cell type endocrine cells showing moderate staining for gastrin. (b) island of small cell type endocrine cells showing marked staining for 5HT. (c) Clump of large cell type endocrine cells showing staining for substance $P$.

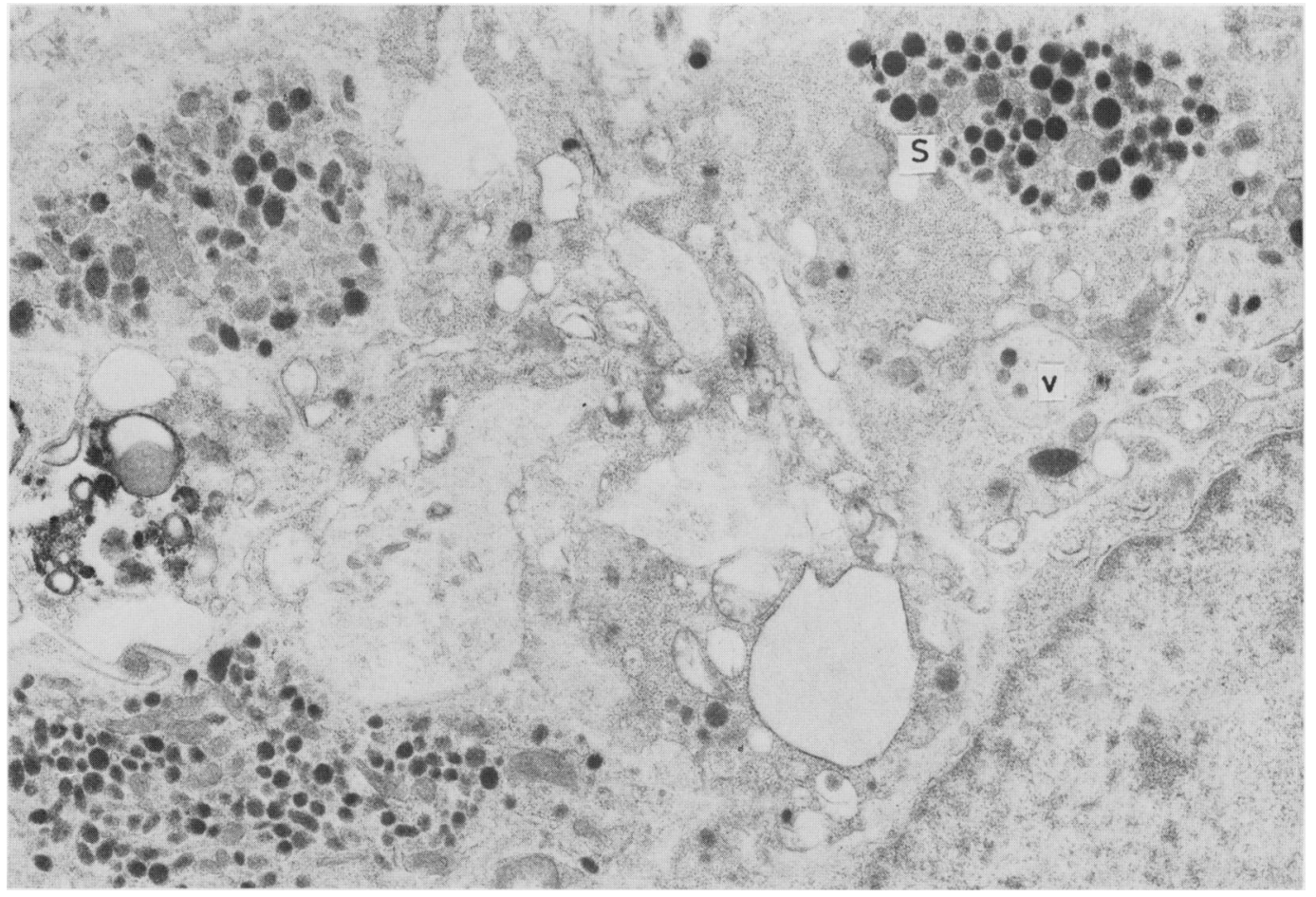

Fig. 5 Part of an isolated island containing two intestinal EC cells and a cell with S-like granules. Also present are three axonal varicosities (v), two of which contain large vesicles. 
Other hormones and neurotransmitters

In three cases staining for SP was seen in intraepithelial large and/or small cells in the proliferative compartment and one case showed occasional SP positive cells within the pyloric type glands. One case showed SP positive extraepithelial aggregates of both cell types and two cases showed SP immunoreactive extraepithelial clumps composed of large cells (Fig. 4c). Staining for SP, in addition, revealed in deeper sections a positive small cell clump in the only patient who did not show any extraepithelial cells upon staining for NSE and PGP 9.5. In one case extraepithelial small cell clumps stained positively for calcitonin and VIP but in none were intraepithelial stainable elements observed. Somatostatin immunoreactivity was only found in rare small intraepithelial cells in one of our cases. ACTH, insulin and glucagon stains were negative in all cases.

\section{ELECTRON MICROSCOPY}

Ultrastructural examination revealed the same distribution of various types of endocrine cells as was seen immunohistochemically with NSE and PGP

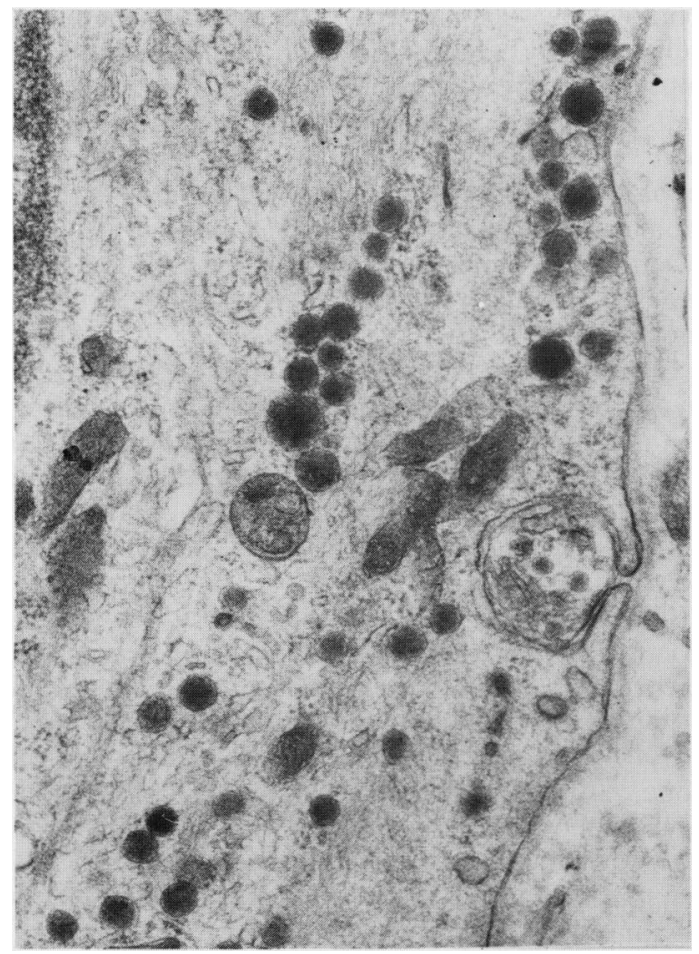

Fig. 6 A small axonal varicosity makes junctional contact with a neuroendocrine cell containing $D, / P$-type granules. Numerous microfilaments and a basal lamina can also be seen.
9.5. Non-granulated cells were seen in the separate islands and were judged to be immature or ungranulated endocrine cells since their general nuclear and cytoplasmic morphology was similar to those containing neurosecretory granules. Among the separate islands of endocrine cells, nerve fibres appeared to be an integral component of some, hence designated neuroendocrine. Axonal varicosities containing both large granular vesicles and large opaque vesicles were observed between the neuroendocrine cells, sometimes indenting them (Fig. 5). Occasionally a small varicosity appeared to make junctional contact with a neuroendocrine cell (Fig. 6) and consisted of asymmetrical thickening of the two apposing membranes. Neuroendocrine complexes were also seen in which several types of neuroendocrine cells mingled with nerve fibres and Schwann cells within a single continuous external lamina.

The secretory granules within the entero- or neuroendocrine cells varied considerably in number. They were usually polarised toward the basal surface of the cell but were sometimes scattered in the cytoplasm. Some cells appeared to have undergone oncocytic change in which the secretory granules were scattered in a cytoplasm packed with pleomorphic mitochondria which probably accounts for the increased size in some of the large cell islands (Fig. 7).

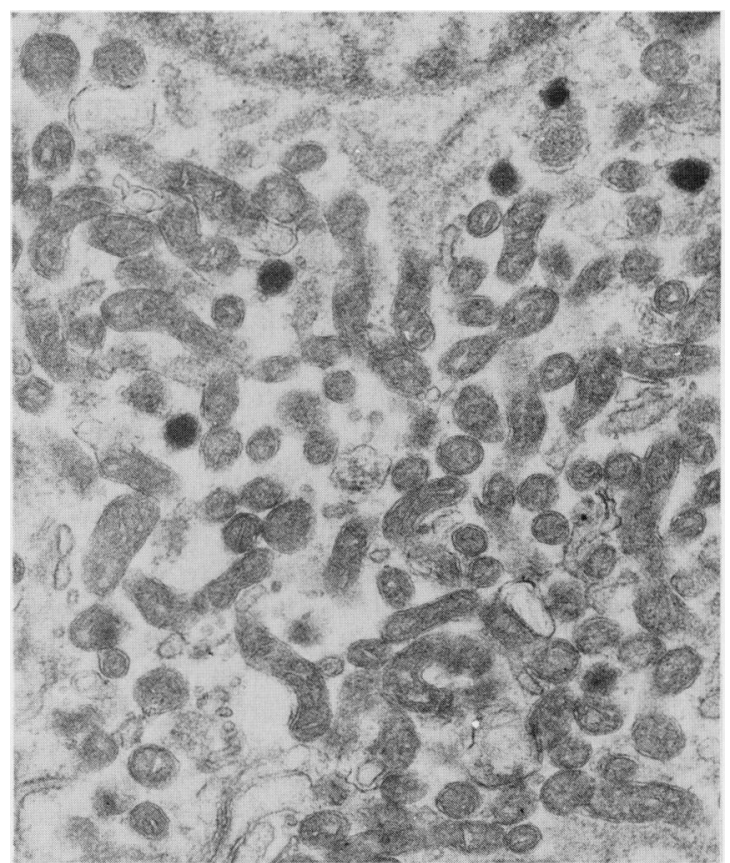

Fig. 7 Cytoplasm of some of the large cells is filled with mitochondria and scattered neuroendocrine granules. 
Using the Lausanne classification of endocrine like cells in human gastroenteropancreatic tissue,$^{16}{ }^{17}$ it was possible to identify, on the basis of granule morphology, several of the entero- and neuroendocrine cells. Nine morphologically distinct types of granules were found some of which correlated with the immunohistochemistry.

\section{Discussion}

Pernicious anaemia is one of the risk conditions for developing stomach carcinoma and pernicious anaemia patients are approximately five times more likely to develop gastric carcinoma than the general population. ${ }^{18}$ Less well recognised and documented in pernicious anaemia patients is an excess risk to develop gastric carcinoid tumour. Less than 50 cases of carcinoids of the stomach in patients with achlorhydria or pernicious anaemia have been reported in the world literature. ${ }^{11} 1319-23$ Carcinoid tumours of the stomach are rare and account for approximately $0.3 \%$ of all stomach tumours. ${ }^{24}$ Three recent reviews found $20 / 189,{ }^{13} 9 / 42^{21}$ and $12 / 30^{23}$ cases of gastric carcinoids to be associated with achlorhydria or pernicious anaemia. Pernicious anaemia patients seem to bear an increased risk to develop carcinoids at least comparable to the risk of developing gastric carcinoma. Gastric carcinoid tumours associated with pernicious anaemia are often small, polypoid and multiple and involve the fundus and body. ${ }^{11} 132123$ They are slow growing tumours and metastasis occurs rarely and late in the course of the disease. ${ }^{11} 13202123$ If metastases occur these are related to the extent and size of the primary tumour. They are seldom observed in patients with primaries measuring less than $2-3 \mathrm{~cm}$ which must penetrate at least through half the gastrointestinal wall. ${ }^{25} 26$

The enteroendocrine cells in the gastric biopsies from our patients with pernicious anaemia show a gradation of change from an intraglandular proliferation, where they form a row of cells surrounding the gland in a basal position, through distortion of the gland by their increasing numbers, to the formation of nodules extending from the base of the glands. Similar transitional phases were also seen by others. ${ }^{13}$ This spectrum is reminiscent of the spontaneous early proliferative stages of the gastric enteroendocrine cells in the rodent Mastomys, which lead, in these animals, to carcinoid tumours. ${ }^{27}$ In many respects socalled carcinoids associated with pernicious anaemia are like those seen arising spontaneously in Mastomys and which are often multiple and rarely metastasise. ${ }^{27}$ We suggest that the endocrine cell proliferation seen in this study is part of an adaptative hyperplastic process in reac- tion to various factors - for example, loss of specialised glands, inflammation, and hypergastrinaemia.

Two types of separate islands of endocrine/ neuroendocrine cells were present in the lamina propria of the gastric biopsies: one solely endocrine and composed of larger cells, in which there was no nervous contact and a second, neuroendocrine and composed of smaller cells, where there was an obvious neural component. This suggests that the former has probably budded from the mucosal epithelium and that the latter arose from the neuroendocrine complex, which is normally present in the lamina propria. ${ }^{28-30}$ Hence a dual origin of gastric carcinoid tumours is also a possibility.

Fasting serum gastrin concentrations had been determined in five of the seven patients during the initial examination four years previously. ${ }^{14}$ In each case these were found to be raised (Table 2). This corresponded with the immunohistochemical findings in the present study. Gastrin immunoreactivity was found to a greater or lesser extent in most areas examined and correlated with cells showing Ggranule morphology. Both immunohistochemistry and electron microscopy indicates the presence of other peptide hormones. Ultrastructurally nine morphologically distinct types of granule containing cells could be distinguished. Somatostatin immunoreactivity was only found in rare intraepithelial cells in one of our cases but ultrastructurally no cells with convincing granules of large D-type morphology were seen. None of our patients suffered from carcinoid syndrome but 5HT immunoreactivity occurred in endocrine/Kultschitzky cells in many areas, particularly those displaying small intestinal metaplasia.

The oncocytic change seen in some groups of hyperplastic enteroendocrine cells is worth noting. Although this phenomenon has not been reported in either gastric endocrine cell hyperplasia or carcinoid tumours associated with pernicious anaemia, it certainly occurs in other lesions of APUD cell origin. $^{31}$

The incidence of upper intestine associated endocrine cells in areas of intestinal metaplasia is in accord with the unitarian theory of the origin of the epithelial cell types in the gastrointestinal tract, ${ }^{32}$ all of which appear to be derived from a stem cell zone. ${ }^{33} \mathrm{~A}$ similar hypothesis of multiple differentiation of neoplastic stem cells, rather than malignant transformation of pre-existing endocrine cells, could be used to explain the occurrence of endocrine tumours of mixed cell population. ${ }^{34}$

In conclusion, we feel that the endocrine proliferations seen in the gastric body mucosa of all seven cases of pernicious anaemia in this series may represent a physiological or adaptive response 
rather than neoplasia. It appears to occur frequently and may provide the basis on which carcinoids develop in some cases. Until these hyperplasias can be more definitely distinguished from neoplasias we think the designation of these lesions as microcarcinoids or carcinoid tumours should be avoided. Comprehension of the pathophysiology of endocrine cell proliferations in pernicious anaemia may contribute to the definition of this difficult distinction between hyperplasia and neoplasia. Documentation and functional analysis of the endocrine cell proliferation in pernicious anaemia is needed in order to elucidate these processes.

We are indebted to Professor N Woolf for generous support and encouragement. We would like to thank Dr A Leathem for advice and $\mathrm{Mr} \mathrm{C}$ Neal for technical assistance. $\mathrm{R}$ Stockbrügger was a holder of a grant from the Swedish Cancer Society during the time of the study ( $\mathrm{RmC}$ 80: 243, project 1276B8002R). Part of this work was supported by MRC grant No $8308615 \mathrm{~N}$ to $\mathrm{R} \mathrm{J}$ Thompson.

\section{References}

1 Editorial. Carcinoid tumours. Changing concepts and new perspectives. Am J Surg Pathol 1984; 8: 295-300.

2 Peranzi G, Lehy T, Bonfils S. L'origine embryologique des cellules endocrines du système digestif: une controverse toujours en cours. Gastroenterol Clin Biol 1984; 8: $560-8$.

3 Rode J, Dhillon AP, Papadaki L, Griffiths D. Neurosecretory cells of the lamina propria of the appendix and their possible relationship to carcinoids. Histopathology 1982; 6: 69-79.

4 Auböck L, Höfler H. Extraepithelial intraneural endocrine cells as starting-points for gastrointestinal carcinoids. Virch Arch [Pathol Anat] 1983; 401: 17-33.

5 Rubin W. Proliferation of endocrine-like (enterochromaffin) cells in atrophic gastric mucosa. Gastroenterology 1969; 57: 641-8.

6 Harris AI, Greenberg H. Pernicious anemia and the development of carcinoid tumors of the stomach. JAMA 1978; 239: 1160-1.

7 Bordi C, Gabrielli M, Missale G. Pathological changes of endocrine cells in chronic atrophic gastritis. An ultrastructural study on peroral gastric biopsy specimens. Arch Pathol Lab Med 1978; 102: 129-35.

8 Wilander E, Grimelius L, Lundquist G, Skoog V. Polypeptide hormones in argentaffin and argyrophil gastroduodenal endocrine tumors. Am J Pathol 1979; 96: $519-30$.

9 Håkanson R, Alumets J, Sundler P. Spontaneous argyrophil cell carcinoid in the glandular stomach: immunohistochemical study of gastric endocrine cells in normal and tumour-bearing mastomys. Scand J Gastroenterol 1979; 14: suppl 53: 27-32.

10 Solcia E, Capella C, Vasallo G. Endocrine cells of the stomach and pancreas in states of gastric hypersecretion. Rend R Gastroenterol 1970; 2: 147-58.
11 Hodges JR, Isaacson P, Wright R. Diffuse enterochromaffin-like (ECL) cell hyperplasia and multiple gastric carcinoids: a complication of pernicious anaemia. Gut 1981; 22: 237-41.

12 Polak JM, Coulling I, Doe W, Pearse AGE. The G cells in pernicious anaemia. Gut 1971; 12: 319-23.

13 Morgan JE, Kaiser CW, Johnson W et al. Gastric carcinoid (gastrinoma) associated with achlorhydria (pernicious anaemia). Cancer 1983; 51: 2332-40.

14 Stockbrügger RW, Menon GG, Beilby JOW, Mason RR, Cotton PB. Gastroscopic screening in 80 patients with pernicious anaemia. Gut 1983; 24: 1141-7.

15 Rode J, Dhillon AP, Doran JF, Jackson P, Thompson RJ. PGP 9.5, a new marker for human neuroendocrine tumours. Histopathology 1985; 9: 147-58.

16 Solcia E, Polak JM, Pearse AGE et al. Lausanne 1977 classification of gastroenteropancreatic endocrine cells. In: Bloom SR, ed. Gut hormones. Edinburgh: Churchill Livingstone, 1978: 40-8.

17 Solcia E, Polak JM, Larsson L-I, Buchan AMJ, Capello C. Update on Lausanne classification of endocrine cells. In: Bloom SR, Polak JM, eds. Gut hormones. Edinburgh: Churchill Livingstone, 1981; 96-106.

18 Ruddell WSJ, Bone ES, Hill CL. Pathogenesis of gastric cancer in pernicious anaemia. Lancet 1978; 1: 521-3.

19 Wilander E, Sundström C, Grimelius L. Pernicious anaemia in association with argyrophil (SevierMunger) gastric carcinoid. Scand J Haematol 1979; 23: 415-20.

20 Goldman H, French S, Burbige E. Kulchitzky cell hyperplasia and multiple metastasizing carcinoids of the stomach. Cancer 1981; 47: 2620-6.

21 Wilander E, El-Salhy M, Pitkanen P. Histopathology of gastric carcinoids: a survey of 42 cases. Histopathology 1984; 8: 183-93.

22 Larsson L-I, Rehfeld JF, Stockbrügger R et al. Mixed endocrine gastric tumors associated with hypergastrinemia of antral origin. Am J Pathol 1978; 93: 53-68.

23 Carney JA, Go VLW, Fairbanks VF, Moore SB, Alport EC, Nora FE. The syndrome of gastric argyrophil carcinoid tumors and non-antral gastric atrophy. Ann Intern Med 1983; 99: 761-6.

24 McDonald RA. A study of 356 carcinoids of the gastrointestinal tract. Am J Med 1956; 21: 867-78.

25 Hajdu SI, Winawar SJ, Myers WPL. Carcinoid tumors. A study of 204 cases. Am J Clin Pathol 1974; 61: 521-8.

26 Johansson $\mathrm{H}$, Wilander E. A clinical study of 30 gastric carcinoids. Upsala J Med Sci 1982; 87: 135-42.

27 Soga J, Kohro T, Tazawa K et al. Argyrophil cell microneoplasia in the Mastomys' stomach - an observation on early carcinoid formation. $J$ Natl Cancer Inst 1975; 55: 1001-6.

28 Stachura J, Krause WJ, Ivey KJ. Ultrastructure of endocrine-like cells in lamina propria of human gastric mucosa. Gut 1981; 22: 534-41.

29 Auböck L, Ratzenhofer M. 'Extraepithelial enterochromaffin cell - nerve-fibre complexes' in the normal human appendix, and in neurogenic appendicopathy. J Pathol 1982; 136: 217-26.

30 Papadaki L, Rode J, Dhillon AP, Dische FE. Fine 
structure of a neuroendocrine complex in the mucosa of the appendix. Gastroenterology 1983; 84: 490-7.

31 Sklar JL, Churg A, Bensch KG. Oncocytic carcinoid tumour of the lung. Am J Surg Pathol 1980; 4: 287-92.

32 Cheng $H$, Leblond $C P$. Origin, differentiation and renewal of the four main cell types in the mouse small intestine. V. Unitarian theory of the origin of the four epithelial cell types. Am J Anat 1974; 141: 537-62.
33 Bjerknes M, Cheng $\mathrm{H}$. The stem-cell zone of the small intestinal epithelium. III. Evidence from columnar, enteroenocrine, and mucous cells in the adult mouse. Am J Anat 1981; 160: 77-91,

34 Larsson L-I. On the possible existence of multiple endocrine, paracrine and neurocrine messengers in secretory cell systems. Invest Cell Pathol 1980; 3: 73-85. 